Canadian University Music Review

Revue de musique des universités canadiennes

\title{
The Canadian Society for Eighteenth-Century Studies / La société canadienne d'étude du dix-huitième siècle: Saskatoon, Saskatchewan, 13-16 October 1994
}

\section{Paul F. Rice}

Numéro 15, 1995

URI : https://id.erudit.org/iderudit/1014398ar

DOI : https://doi.org/10.7202/1014398ar

Aller au sommaire du numéro

\section{Éditeur(s)}

Canadian University Music Society / Société de musique des universités canadiennes

\section{ISSN}

0710-0353 (imprimé)

2291-2436 (numérique)

Découvrir la revue

Citer ce compte rendu

Rice, P. F. (1995). Compte rendu de [The Canadian Society for

Eighteenth-Century Studies / La société canadienne d'étude du dix-huitième siècle: Saskatoon, Saskatchewan, 13-16 October 1994]. Canadian University Music Review / Revue de musique des universités canadiennes, (15), 156-157. https://doi.org/10.7202/1014398ar

All Rights Reserved (C Canadian University Music Society / Société de musique des universités canadiennes, 1995
Ce document est protégé par la loi sur le droit d'auteur. L'utilisation des services d'Érudit (y compris la reproduction) est assujettie à sa politique d'utilisation que vous pouvez consulter en ligne.

https://apropos.erudit.org/fr/usagers/politique-dutilisation/ 
subjects, Sophie Eckhardt-Gramatté, Mary Travers ("La Bolduc"), and Gena Branscombe, were chosen to reflect a broad spectrum of personal experience and musical idiom: the passionate commitment of Eckhardt-Gramatté, the earthiness of Bolduc, the intellectualism of Branscombe. The scripts were compiled by the students themselves as part of a class project, and each dramatic scene was followed by a performance of the composer's music.

To conclude the scheduled activities a round table of all the speakers fielded questions and comments from the floor, including the relation of some personal experiences with Pentland and Eckhardt-Gramatté. The papers of the Conference are to be published by the Humanities Research Group of the University of Windsor as part of their series: "Working Papers in the Humanities."

\section{The Canadian Society for Eighteenth-Century Studies/La société canadienne d'étude du dix-huitième siècle}

Saskatoon, Saskatchewan

13-16 October 1994

\section{Paul F. Rice}

The twentieth conference of this society was held at the Delta Bessborough Hotel in Saskatoon from 13-16 October 1994, under the sponsorship of the University of Saskatchewan. The task of organizing this complex event was intrusted to the capable hands of Alex Sokalski (Conference President) and PeterLoptson (VicePresident) who, along with a large team of able volunteers, oversaw the smooth running of four simultaneous sessions of papers. Delegates attended from France, Spain, Canada and the United States.

The theme of the conference was "Reason and Unreason/raison et déraison". In addition to four plenary sessions, 102 individual papers were delivered, with topics that explored a wide range of interests in the social, political, artistic and scholarly pursuits of eighteenth-century life. The interdisciplinary nature of this society was reflected in sessions that ranged from the "History of Science" to "Gardens, Symbolic Space and Pope" and from "Pornography and Pornographers" to "The German Enlightenment". Four music papers presented aspects of eighteenth-century musical life within a socio-historical context: (1) J. Richard Raum (University of Regina) "18th-Century Society and the Professional Musician: Thomas Geschladt, A Case History," (2) Paul F. Rice (Memorial University of Newfoundland) "Power, Politics and the Production of Opera: Madame de Pompadour, Mondonville and Rameau," (3) Gordana Lazarevich 
(University of Victoria) "The Musical Libertine in Mozart's Vienna: How Art Reflected Life", and (4) Jack Eby (Bishop's University) "François Giroust and Félix Nogaret: Making Revolutionary Music in Versailles."

Live music made a welcome addition to the spoken word at the conference. Members of the University of Saskatchewan Wind Orchestra presented a spirited account of Mozart's Serenade in B-flat major, KV 361 ("Grande Partitta") under the direction of Marvin Eckroth (University of Saskatchewan) at the hotel. An evening concert was presented at the Anglican Cathedral of St. John which featured flautist Walter Kreyszig (University of Saskatchewan) and harpsichordist and pianist India Dennis (University of Ohio). The concert was entitled "Musical Theorists and Theoretical Musicians" and featured music by Quantz, Mattheson, Richter, Türk, C. P. E. Bach, Kirnberger, Telemann, W.A. Mozart, Wagenseil, Agrell and L. Mozart. Of particular interest was the use of Kirnberger's system of "Well Tempered" tuning for the harpsichord. Another conference highlight was the presentation of Marivaux's play La Colonie, presented in a new English translation by David Edney and directed by Margaret Kyle, both of the University of Saskatchewan. Students from the Department of Music at the University of Saskatchewan provided live music both before and during the performance of this play.

I am pleased to announce that the twenty-first meeting of the society will be hosted by the University of Windsor, 11-15 October 1995. The conference theme will be "Frontiers and Freedom/Frontières et Émancipation." The formal call for papers will be made in early 1995 . The society has a strong interest in music (and in the fine and performing arts in general), and I encourage those with similar interests to consider submitting an abstract for this conference. The society publishes a select number of the conference papers in its journal Lumen (formerly Man and Naturell'Homme et la nature). Those wishing to join the society should contact Dr. Paul Wood, Department of History, University of Victoria, P.O. Box 3045, Victoria, B.C., V8W 3P4. 